\title{
THE EFFECT OF LEARNING MEDIA AND INTEREST IN LEARNING ON ENGLISH LEARNING OUTCOMES
}

\author{
Reni Apriani \\ STKIP La Tansa Mashiro, Rangkasbitung, Indonesia \\ Reniapriani776@yahoo.co.id
}

\begin{abstract}
This study aims to determine the Effect of Learning Media Influence and Interest in Learning Outcomes of English in Public Junior High School Students in Lebak Banten. Furthermore,the researcher to find out the effect of learning media interaction and learning interest on learning outcomes using the quantitative experiment method. This study used population of 583 students and sample of 70 students. The research hypotheses tested include: 1) There is a significant effect of learning media on learning outcomes. 2) There is a significant effect of interest in learning on learning outcomes. 3) There is a significant interactive influence on learning media and interest in learning about learning outcomes. Then from the results of the hypothesis test, it was found that 1) there is a significant effect of learning media on the learning outcomes of English students of Lebak region at Junior High School. This is evidenced by the acquisition of the Sig. $=0,000<0,05$ and F count $=16,334$. 2) There is a significant effect of interest in learning on the learning outcomes of English students in Lebak region at Junior High School. This is evidenced by the acquisition of Sig. = $0,000<0,05$ and $\mathrm{F}$ count $=15,127.3)$ There is a significant interaction effect of learning media and learning interest in the learning outcomes of English students of Lebak region Junior High School. This is evidenced by the acquisition of Sig. $=0,000<0,05$ and $\mathrm{F}$ count $=$ 13,833 .
\end{abstract}

Keywords: Learning Media; Interest to learn; Learning outcome

\section{INTRODUCTION}

Education is an important factor for the sustainability of a nation because education can improve the main elements of the nation, namely human resources. Well educated human resources are able to manage other resources. Therefore, their utilization can be optimized for the welfare of the nation. Conversely, if the nation has low resources they will be left behind by other countries since the people are unable to optimize the potential of the nation. Therefore, these key elements must be properly maintained through good education, right and directed, and processes therefore the gradual increase continues to trigger and accelerate and support other activities in nation-building, abstracted from Law No. 20 year 2003 concerning national education goals (Law no.20 year 2003).

Good education should continually escorted by the government through a curriculum with various strategies. The curriculum must be improved along with the desired level of progress and acceleration according to the large target of the direction of national education policy so that it is expected that the achievement of national intelligence can be harmonized with accelerating progress and competition with other nations.

The curriculum at Junior High Schools considers that English is an 
important subject, where in fact English language lessons have been given to all students from elementary school up to university level, even in some places that have been introduced since kindergarten. It is done to equip students with the ability to communicate in English as an international language. International languages, especially English, are very widely used both in science and business, Susanto (2014: 12). The results of learning English that has been implemented in Indonesia are considered less successful, as evidenced by the achievements of Indonesian students, both at the national level and the international level. Students' achievement is still low compared to other countries. English First (EF) issued the latest research results, the EF English Proficiency Index (EPI). The usefulness of the index is to measure the average level of English language skills of adults in a country. In its fifth edition, EFI surveyed 910,000 adults aged 18-30 years in 80 countries who conducted tests online. As a result, Indonesia ranks at the $32^{\text {nd }}$ and at the Asian level, Indonesia is ranked eighth under Singapore. EPI Index (2015; 34).

In Cikulur Public Junior High School 1 the level of English Language scores is relatively low compared to other public Junior High Schools in the Lebak Regency region Based on the data from the Education and Culture Office of Lebak Region, the English grade rating of the Junior High School 1 Cikulur is still below the top 10. According to Anni (2006: 4), learning outcomes can be seen from the changes in behavior after learning activities.. Usman (2002; 27), states learning outcomes are influenced by the interest in learning. At last, Windradini in Sardini (2013: 13) states that "an activity carried out not in accordance with interest will result in unpleasant performance". Interest in learning can be built using the right learning media, one of which is using media assistive technology, for example, audiovisual, tape recorders, CDs, films and more.

One of the English language learning materials taught at Junior High School class IX at the first semester is writing, Descriptive writing, reading and speaking. There are several media used in learning English, for example, using audiovisual, computer, CD, VCD, LED TV and web-based computers and In Focus devices. Besides the teaching media, the teacher is usually also using other media such as flipchart paper, meta plan, and others. According to DePorter (2002: 194), a descriptive writing method is done by giving instructions on how to write descriptive, using computer media to display images and tell related images to students. Students are stimulated by interesting images so that They can create storytelling in the contest of national storytelling, both in terms of the selection of words or sentences and from ideas and story ideas themselves. As the focus of research in observing researchers, researchers used a Learning Implementation Plan (RPP) consisting of 1) Communication skills, 2) grammar practice, 3) Developing skills, 4) Pronunciation and 5) Self-test units. RPP as a reference for learning in the classroom in this study in its implementation is divided into two groups. First group used audiovisual learning media and the second group used conventional learning.

Communication skills include recording dialogues, recording using why and because conversations that contain expressions. While the practice grammar includes, an explanation of the interrogative negative sentence simple present and the explanation of negative interrogative sentences and a list of questions and answer choices. For 
developing skills, researchers use interview records and record conversations. Then for pronunciation, researchers use recorded conversations with the intonation of interrogative sentences and positive sentences. Furthermore, for the self-test unit, researchers use your record voice, which is recording conversations concerning instructions.

The results of preliminary observation can be seen with show that some students stated that English lessons were less interesting, even boring. They consider that English language lessons are difficult because they found that they find difficult to understand and memorize. With this opinion, it implies the low interest and quality of students in teaching English. The factors that influence student learning can be divided into two, namely:

1. Internal factors (factors from within students), namely:

a. Students' interest in learning English is low.

b. Students are lazy to speak English.

c. There are many students who believe that English is unimportant to support further education.

many factor from external or outside. More factors from technologies are laptops, LCD, notebooks, etc. another factor come from the teachers because they are lack of four English skills are Speaking, Listening, Writing and Reading. The time allocated is not sufficient.

2. The teaching media are relatively lack, learning strategies are low and methods tend to be monotonous, there is no native speaker.

\section{METHOD}

According to Sugiyono (2013: 6), educational research methods can be interpreted as scientific ways to obtain valid data, that is developed and proven, so that in turn it can be used to understand, solve and anticipate problems in the field of education. The research method is a scientific way to get data with specific purposes and uses. The purpose of this study is to obtain the most effective learning model in improving students' learning outcomes, the research method used is the experimental method.

Meanwhile, the experimental research method is a way to find a causal relationship between two factors deliberately caused by researchers by eliminating or reducing other factors that interfere. (Arikunto, 2010: 9).

This research is designed by using a quantitative approach. This approach is chosen to analyze the effect of many independent variables on the dependent variable, relying on data from experimental designs. In line with the problems investigated and the objectives of the study that have been set, the method used in this study is an experimental method using 2way ANOVA analysis. This technique is used to analyze the effect that exists between the factors that are assumed to give influence on the learning outcomes. The variables mentioned are learning media (X1), learning interest (X2) and learning outcomes $(\mathrm{Y})$.

\section{RESULTS AND DISCUSSION}

In this study there are three variables studied, namely learning media and learning interest as independent variables and English learning outcomes as the dependent variable. In other words, this research is a study consisting of two independent factors, there are learning 
media (A) and learning interest (B). Each factor consists of sub-factors called levels. For learning media (A) are two levels, is like audio visual (A1) and conventional
(A2). The second factor is interest in learning (B) with two levels, are : high (B1) and low (B2).

Table 1. Descriptive statistics

\begin{tabular}{|c|c|c|c|c|}
\hline \multirow{2}{*}{\multicolumn{5}{|c|}{\begin{tabular}{|l|} 
Descriptive Statistics \\
Dependent Variable: Results of Learning English \\
\end{tabular}}} \\
\hline & able: Results of & Learnin & glish & \\
\hline $\begin{array}{l}\text { Instructional } \\
\text { Media }\end{array}$ & Minat Belajar & Mean & $\begin{array}{l}\text { Std. } \\
\text { Deviation }\end{array}$ & $\mathrm{N}$ \\
\hline \multirow{3}{*}{ Audiovisual } & High & 88.89 & 5.572 & 18 \\
\hline & Low & 75.00 & 7.906 & 17 \\
\hline & Total & 82.14 & 9.723 & 35 \\
\hline \multirow{3}{*}{ Conventional } & High & 74.72 & 8.130 & 18 \\
\hline & Low & 74.41 & 8.639 & 17 \\
\hline & Total & 74.57 & 8.258 & 35 \\
\hline \multirow{3}{*}{ Total } & High & 81.81 & 9.939 & 36 \\
\hline & Low & 74.71 & 8.160 & 34 \\
\hline & Total & 78.36 & 9.733 & 70 \\
\hline
\end{tabular}

Based on the data above, It shows that for the learning outcomes of English students who used audio-visual learning media and had a high interest in learning consisted of 18 students had an average value of 88.89 and a standard deviation of 5.572. For English learning outcomes students who use audiovisual learning media and have low interest in learning consist of 17 students having an average value of 75 and a standard deviation of 5.572 .
For the results of learning English, students who use conventional learning media and have a high interest in learning consist of 18 students having mean score of 74.72 and a standard deviation of 8.130. For the results of learning English, students who use conventional learning media and have low interest in learning consist of 17 students who have a mean score of 74.41 and a standard deviation at 8.639 .

Table 2. Statistics Description according to the Research Design

\begin{tabular}{|c|c|c|c|c|}
\hline \multirow[b]{2}{*}{ B } & \multirow[t]{2}{*}{ Stat } & \multicolumn{2}{|l|}{ A } & \multirow[t]{2}{*}{ Total } \\
\hline & & $\overline{A_{1}}$ & $\mathrm{~A}_{2}$ & \\
\hline \multirow{3}{*}{$B_{1}$} & $\mathrm{~N}$ & 18 & 17 & 35 \\
\hline & $\hat{X}$ & 88.89 & 74.72 & 81.81 \\
\hline & $S$ & 5.572 & 8.130 & 9.939 \\
\hline \multirow{3}{*}{$B_{2}$} & $\mathrm{~N}$ & 18 & 17 & 35 \\
\hline & $\hat{X}$ & 75.00 & 74.41 & 74.71 \\
\hline & $S$ & 7.906 & 8.639 & 8.160 \\
\hline \multirow{3}{*}{ Total } & $\mathrm{N}$ & 36 & 34 & 70 \\
\hline & $X$ & 82.14 & 74.57 & 78.36 \\
\hline & $\mathrm{S}$ & 9.723 & 8.258 & 9.733 \\
\hline
\end{tabular}




\section{A. Test Data Analysis Requirements}

Before testing hypotheses, test requirements analysis is carried out first, which includes testing for normality and homogeneity.
In this case, this research will be continued with parametric analysis, namely Analysis of Variance (ANOVA) or using the general linear model (GLM) analysis.

1. Normality Test

Table 3. Normality Test Error

\begin{tabular}{|l|l|l|}
\hline \multicolumn{3}{|l|}{ One-Sample Kolmogorov-Smirnov Test } \\
\hline \multicolumn{2}{|l|}{} & $\begin{array}{l}\text { Learning English } \\
\text { outcome }\end{array}$ \\
\hline $\mathrm{N}$ & 70 \\
\hline $\begin{array}{l}\text { Normal } \\
\text { Parameters, }\end{array}$ & $\begin{array}{l}\text { Mean } \\
\text { Std. } \\
\text { Deviation }\end{array}$ & 78.36 \\
\hline $\begin{array}{l}\text { Most Extreme } \\
\text { Differences }\end{array}$ & $\begin{array}{l}\text { Absolute } \\
\text { Positive }\end{array}$ & .148 \\
\hline Kolmogorov-Smirnov Z & -148 \\
\hline Kolive & -.099 \\
\hline Asymp. Sig. (2-tailed) & 1.235 \\
\hline \begin{tabular}{l} 
a. Test distribution is Normal. \\
\hline b. Calculated from data.
\end{tabular} \\
\hline
\end{tabular}

Based on the table 3 shows that the value of the Kolmogorov-Smirnov $\mathrm{Z}=1,235$ statistical test, and all Sig value $=0,095>0,05$. This means that all the data above is normally distributed.
2. Homogeneity Test

Homogeneity testing on learning media data was carried out by Levene's test at a significance level $5 \%$.

Table 4. Homogeneity Test

\begin{tabular}{|c|c|c|c|c|}
\hline Levene's T & t of Equali & $y$ of $\mathrm{Er}$ & or Varian & \\
\hline $\begin{array}{l}\text { Dependent } \\
\text { Inggris }\end{array}$ & Variable: & Hasil & Belajar & Bahasa \\
\hline $\mathrm{F}$ & df1 & df2 & Sig. & \\
\hline .407 & 3 & 66 & .749 & \\
\hline $\begin{array}{l}\text { Tests the } \\
\text { of the dep }\end{array}$ & ent varia & $\begin{array}{l}\text { S that } \\
\text { is equ }\end{array}$ & $\begin{array}{l}\text { he error } \\
\text { al across }\end{array}$ & $\begin{array}{l}\text { ariance } \\
\text { roups. }\end{array}$ \\
\hline a. Design: & tercept + & $+\mathrm{B}+$ & $* \mathrm{~B}$ & \\
\hline
\end{tabular}

From the table above obtained data $\mathrm{Fo}=$ 0.407 and Sig. $=0.749>0.05$. This means that the data comes from homogeneous samples. Thus, the null hypothesis is accepted. This means the sample comes from a population that has the same variance (homogeneous). This applies from the testing of normality and homogeneity above, it can be concluded that the requirements that must be met by 
research data to be processed with the ANOVA technique have been fulfilled.

\section{B. Test the Hypothesis}

After the normality and homogeneity tests were carried out and the results showed that the study sample came from the population of normal distribution and homogeneous sample variance, then hypothesis testing using ANOVA could be done.

Analysis of student learning outcomes data was carried out using two- way ANOVA whose homo cess calculations were assisted with SPSS 20 homework. The ANOVA test results were then followed by an F test to find out the significance of the differences between each group. In other words, the F test is used to see which sample groups are higher in English learning outcomes of students in terms of learning interest.

A summary of the results of data analysis using ANOVA can be seen in the following table:

Table 5. Test the Research Hypothesis

\begin{tabular}{|l|l|l|l|l|l|}
\hline \multicolumn{6}{|l|}{ Tests of Between-Subjects Effects } \\
\hline Dependent Variable: Hasil Belajar Bahasa Inggris \\
\hline Source & $\begin{array}{l}\text { Type } \\
\text { Sum of } \\
\text { Squares }\end{array}$ & $\begin{array}{l}\text { Mean } \\
\text { Square }\end{array}$ & F & Sig. \\
\hline $\begin{array}{l}\text { Corrected } \\
\text { Model }\end{array}$ & $2690.565^{\text {a }}$ & 3 & 896.855 & 15.393 & .000 \\
\hline Intercept & 428327.088 & 1 & 428327.088 & 7351.33 & .000 \\
\hline A & 951.691 & 1 & 951.691 & 16.334 & .000 \\
\hline B & 881.374 & 1 & 881.374 & 15.127 & .000 \\
\hline A B & 805.977 & 1 & 805.977 & 13.833 & .000 \\
\hline Error & 3845.507 & 66 & 58.265 & & \\
\hline Total & 436325.000 & 70 & & & \\
\hline Corrected & 6536.071 & 69 & & & \\
\hline Total & 69 & & & \\
\hline a. R Squared $=.412$ (Adjusted R Squared $=.385)$ & \\
\hline
\end{tabular}

Based on the data above, the proposed research hypothesis can be answered. The explanation of the table above is as follows:

1. First Hypothesis: There is a significant effect of learning media on the students' English learning outcomes at Public Junior High School 1 Cikulur in Lebak. Based on table 5, ANOVA results show that'with the Sig. $=0,00<0,05$ and $\mathrm{F}$ count $=16,334$, then the null hypothesis (Ho) is rejected and the research hypothesis (H1) is accepted. This means that there is a significant effect of learning media on the learning outcomes of English students at Junior High School 1 Cikulur in Lebak Region, or in other words, there are differences in English learning outcomes of students who use audiovisual learning media with those using conventional learning media. 
2. Second Hypothesis: There is a significant effect of interest in learning on students' English the learning outcomes at Public Junior High School 1 Cikulur, Lebak Region.

Based on table 5, ANOVA results are obtained with the Sig. $=0,00<0,05$ and $F$ count $=15.127$, then the null hypothesis (Ho) is rejected and the alternative hypothesis (H1) is accepted. This means that there is a significant effect of interest in learning on students' learning outcomes in English at Junior High School in Lebak region. In other words, there are differences in learning outcomes of English students who have a high interest in learning with those who have low interest in learning.

3. Third Hypothesis: there is a significant interaction effect of learning media and interest in learning towards students' English learning outcomes at Public Junior High School 1 Cikulur in Lebak Region.
Based on table 5, ANOVA results show that'the Sig. $=0,00<0,05$ and F count $=13,833$, then the null hypothesis (Ho) is rejected and the alternative hypothesis (H1) is accepted. This means that there is a significant interaction effect on the use of instructional media and interest in learning towards the students' English learning outcomes at Junior High School 1 Cikulur in Lebak Region. Meanwhile, the value of Adjusted R. Squared of 0.412 means that the results of learning English in students who use learning media and Have interest in learning in learning have an effect of $41.2 \%$ on the improvement of English learning outcomes of Lebak region of Junior High School students.

\section{Advanced Test}

In line with the occurrence of significant interactions of learning media and interest in learning about learning outcomes in English, further testing is needed. The further test used is the Tukey test.

Table 6. Further testing

\begin{tabular}{|c|c|c|c|c|c|c|}
\hline \multicolumn{7}{|c|}{ Multiple Comparisons } \\
\hline \multicolumn{7}{|c|}{$\begin{array}{l}\text { Dependent Variable: English Learning Outcome } \\
\text { Tukey HSD }\end{array}$} \\
\hline \multirow{4}{*}{$\begin{array}{l}\text { (I) } \\
\text { Hoc }\end{array}$} & \multirow{4}{*}{$\begin{array}{r}\operatorname{Post}(\mathrm{J}) \\
\text { Hoc }\end{array}$} & \multirow{4}{*}{\begin{tabular}{l|l} 
Post & Mean \\
& Difference (I- \\
J)
\end{tabular}} & \multirow{4}{*}{$\begin{array}{l}\text { Std. } \\
\text { Error }\end{array}$} & \multirow[t]{4}{*}{ Sig. } & \multirow{2}{*}{\multicolumn{2}{|c|}{$\begin{array}{l}\text { Confidence } \\
\text { al }\end{array}$}} \\
\hline & & & & & & \\
\hline & & & & & Lower & Upper \\
\hline & & & & & Bound & Bound \\
\hline \multirow{3}{*}{ A1B 1} & A1B2 & $13.89^{*}$ & 2.582 & .000 & 7.08 & 20.69 \\
\hline & A2B1 & $14.17^{*}$ & 2.544 & .000 & 7.46 & 20.87 \\
\hline & $\mathrm{A} 2 \mathrm{~B} 2$ & $14.48^{*}$ & 2.582 & .000 & 7.67 & 21.28 \\
\hline \multirow{3}{*}{ A1B2 } & A1B 1 & $-13.89^{*}$ & 2.582 & .000 & -20.69 & -7.08 \\
\hline & A2B 1 & .28 & 2.582 & 1.000 & -6.53 & 7.08 \\
\hline & A2B2 & .59 & 2.618 & .996 & -6.31 & 7.49 \\
\hline \multirow{3}{*}{ A2B 1} & A1B1 & $-14.17^{*}$ & 2.544 & .000 & -20.87 & -7.46 \\
\hline & $\mathrm{A} 1 \mathrm{~B} 2$ & -.28 & 2.582 & 1.000 & -7.08 & 6.53 \\
\hline & A2B2 & .31 & 2.582 & .999 & -6.49 & 7.11 \\
\hline A2B2 & A1B 1 & $-14.48^{*}$ & 2.582 & .000 & -21.28 & -7.67 \\
\hline
\end{tabular}


The Effect of Learning Media and Interest in Learning on English Learning Outcomes (Reni Apriani)

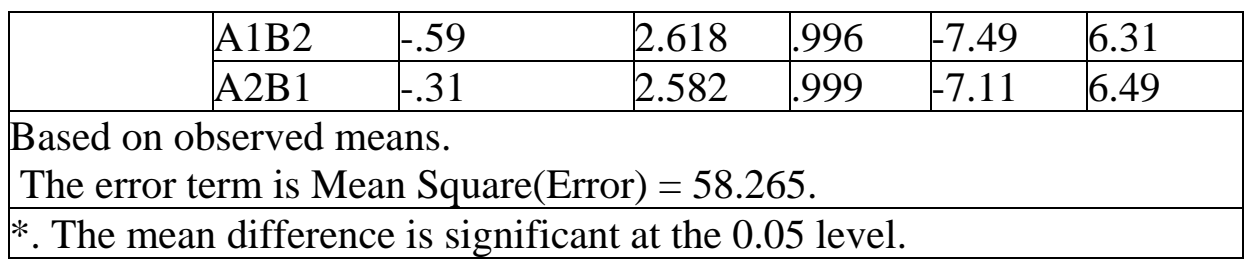

Based on the further tests above, it can be concluded as follows:

1) In groups $A 1 B 1$ and $A 1 B 2$, it can be seen that the Difference Mean is 13.89 , meaning that the difference between the averages of A1B1 and A1B2 groups is 13.89. This value is quite large and can be proven with a significance value of $0,00<0,05$, or it can be interpreted that specifically for group A1, there are significant differences in the English learning outcomes between groups B1 and B2.

2) In groups $\mathrm{A} 1 \mathrm{~B} 1$ and $\mathrm{A} 2 \mathrm{~B} 1$ it can be seen that the Difference Mean is 14.17, meaning that the difference between the averages of groups A1B1 and A2B1 is 14.17. This value is quite large and can be proved by a significance value of $0.010<0.05$, or it can be interpreted that specifically for group B1, there are significant differences in the English learning outcomes between groups A1 and A2.

3) In groups $\mathrm{A} 1 \mathrm{~B} 2$ and $\mathrm{A} 2 \mathrm{~B} 2$, it can be seen that the Difference Mean is 0.59, meaning that the difference between the mean groups $\mathrm{A} 1 \mathrm{~B} 2$ and $\mathrm{A} 2 \mathrm{~B} 2$ is 0.59 . This value is quite small and can be proved by a significance value of $0.996>0.05$, or it can be interpreted that specifically for group B2, there are significant differences in the English learning outcomes between groups A1 and $\mathrm{A} 2$.

4) In groups $\mathrm{A} 2 \mathrm{~B} 1$ and $\mathrm{A} 2 \mathrm{~B} 2$, it can be seen that the Difference Mean is 0.31, meaning that the difference between the averages of $\mathrm{A} 2 \mathrm{~B} 1$ and $\mathrm{A} 2 \mathrm{~B} 2$ groups is 0.31 . This value is quite large and can be proved by a significance value of $0.999>0.05$, or it can be interpreted that specifically for group A2, there are significant differences in the English learning outcomes between groups B1 and B2.

\section{DISCUSSION}

There is a significant effect of the use of instructional media on the students' English learning outcomes at Public Junior High School 1 Cikulur in Lebak Region.

Based on the results of the study which tated that the use of learning media has a significant influence on improving the students' English learning outcomes at Public Junior High School 1 Cikulur in Lebak Region. In other words, there are differences in English learning outcomes of students who use audiovisual learning media with those using conventional learning media. This can be seen from the average value of English learning outcomes of students using audiovisual learning media of 82.14 , while the average value of learning outcomes of English students using conventional learning media is 74.57 .

One of the English language learning materials taught at junior high school level IX in the first semester is communication practice, grammar practice, Developing skills and pronunciation. There are several media used in learning English, for example, using audio-visual, computer, CD, VCD, LED TV and web-based computers and InFocus devices. Besides the media infrastructure, the teacher is usually also using other media such as flipchart paper, meta plan, and many other 
maintenance tools. According to DePorter (2002; 194), the writing method is done by giving instructions on how to write the following grammatical and can also use computer media to display images and tell related images to students. Students are stimulated by interesting images so that their power can create creations in storytelling, both from the perspective of words or sentences, as well as from ideas and story ideas themselves.

In addition, Yusufhadi Miarso (2004: 458) suggest that media in the learning process tends to be interpreted graphical, photographic or electronic tools to capture, process and reconstruct the information and reconstruct visual or verbal information. Whereas, according to Hamalik (2005: 15), learning media is everything that can be used to channel messages (learning material), so that it can stimulate the attention, interests, thoughts, and feelings of the learning in learning activities to achieve certain learning goals. The use of instructional media in addition to providing stimuli for students to the learning process, learning media also has an important role in supporting the quality of the teaching and learning process.

The benefits of learning media according to Sudjana and Rivai (2005: 32) about the use of teaching media in student learning processes, as follows:

a) Teaching will attract students' attention so that it can foster learning motivation.

b) The teaching material will be more clearly defined and delivered so that it can be better understood by students and allows students to master the teaching goals better.

c) Teaching methods will be more varied, not merely verbal communication through the words spoken by the teacher so that students are not bored and the teacher does not run out of energy, especially if the teacher must teach for each lesson.

d) Students do more learning activities, because they not only listen to the teacher's description, but also other activities such as observing, doing, demonstrating, and so on.

In essence, it is not the media of learning itself that determines learning outcomes. It turns out that the success of using learning media in the learning process to improve learning outcomes depends on (1) the content of the message, (2) how to explain the message, and (3) the characteristics of the recipient of the message. Thus, in choosing and using media, these three factors need to be considered. If the three factors can be delivered in learning media, of course, they will give maximum results.

\section{There is a significant effect of learning interest on the students' English learning outcomes at Public Junior High School 1 Cikulur in Lebak}

Based on the results of the study, the role of interest in learning has a significant effect on improving the students' English learning outcomes at Public Junior High School 1 Cikulur in Lebak Region. In other words, English learning outcomes of students who have high learning interest are better than English learning outcomes of students who have low interest in learning. This can be seen from the mean of learning outcomes of English students who have a high learning interest of 81.81, while the mean of learning outcomes of English students who have low learning interest is 74.71 .

\section{There is a significant interaction effect of learning media and interest in learning towards the students' English learning}


outcomes at 1 Public Junior High School 1 Cikulur in Lebak Region

Based on the results of the study, it can be stated that learning media and learning interests provide significant interaction effects on improving the students' English learning outcomes at Public Junior High School 1 Cikulur in Lebak Region. This effect is quite large and very significant. The Suitable learning media given to students during teaching have a great impact on students in absorbing knowledge. There are many media in English. As contained in the RPP (lesson plan) media used in the delivery of material in class using images and tapes. Pictures are very helpful for students who are capable of linguistic vials in absorbing the material presented. Whereas, for tape recorder used can help students get used to listening to English conversations.

\section{CONCLUSION}

Based on the results of the research hypothesis testing, some conclusions are drawn as follows: There is a significant effect of learning media on the students' English learning outcomes at Public Junior School 1 Cikulur Lebak region. It is evidenced by the acquisition of the Sig. = $0,000<0,05$ and $\mathrm{F}$ count $=16,334$. There is a significant effect of students' learning interest on their English learning outcomes at Public Junior School 1 Cikulur Lebak region. This is evidenced by the acquisition of Sig. $=0,000<0,05$ and $\mathrm{F}$ count $=15,127$, There is a significant interaction effect of learning media and learning interest on the students' English learning outcomes at Public Junior High School 1 Cikulur in Lebak region. This is evidenced by the acquisition of Sig. = $0,000<0,05$ and $\mathrm{F}$ count $=13,833$.

\section{Further test results state:}

In the A1B1 and A1B2 groups, the Difference Mean was 13.89 , meaning that the difference between the A1B1 and A1B2 groups was 13.89. This value is quite large and can be proven with a significance value of $0,000<0.05$, or it can be interpreted that specifically for group A1, there are significant differences in the results of learning English between groups $\mathrm{B} 1$ and $\mathrm{B} 2$. In groups $\mathrm{A} 1 \mathrm{~B} 1$ and $\mathrm{A} 2 \mathrm{~B} 1$, it can be seen that the Difference Mean is 14.17, meaning that the difference between the averages of $\mathrm{A} 1 \mathrm{~B} 1$ and $\mathrm{A} 2 \mathrm{~B} 1$ groups is 14.17. This value is quite large and can be proven with a significance value of 0.010 $<0.05$, or it can be interpreted that specifically for group B1, there are significant differences in the results of learning English between groups A1 and A2. In groups A1B2 and A2B2, it can be seen that the Difference Mean is 0.59, meaning that the difference between the mean $\mathrm{A} 1 \mathrm{~B} 2$ and $\mathrm{A} 2 \mathrm{~B} 2$ groups is 0.59 . This value is quite small and can be proven with a significance value of $0.996>0.05$, or it can be interpreted that specifically for group B2, there are insignificant differences in English learning outcomes between groups $\mathrm{A} 1$ and $\mathrm{A} 2$. In groups $\mathrm{A} 2 \mathrm{~B} 1$ and $\mathrm{A} 2 \mathrm{~B} 2$, it can be seen that the Difference Mean is 0.31 , meaning that the difference between the mean groups A2B1 and $\mathrm{A} 2 \mathrm{~B} 2$ is 0.31 . This value is quite large and can be proven by a significance value of $0.999>0.05$, or it can be interpreted that specifically for group A2, there are insignificant differences in the English learning outcomes between groups B1 and B2.

\section{REFERENCES}

Ahmad Susanto.(2014) . Teori Belajar dan Pembelajaran di Sekolah Dasar, (Jakarta: Kencana Prenada Media Group) 
Anni, Catharina, T.(2006). Psikologi belajar. Semarang: Universitas Negeri Semarang, Press.

Arikunto, Suharsimi. 2010. Prosedur Penelitian Suatu pendekatan Praktek. Jakarta: Rineka Cipta.

DePorter, Bobbi \& Hernacki, Mike. 2006. Quantum Learning: Membiaasakan Belajar Nyaman \& MEnyenangkan. Bandung: PT.Mizah Pustaka

Djali,D. (2008). Psikologi pendidikan . Jakarta : PT. Bumi Aksara

Djamarah, Bahri, S dan Zain S. (2004). Staretgi belajar mengajar. Jakarta : PT. Rineka Cipta.

Ef Epi (2015) EF English Proficienty Index.www.ef.com Education First ltd.all Right Reserved.

Gerlach, Vernon S. \& Donald P. Ely.(1980). Teaching \& Media: A Systematic approach. second edition, Englewood Cliffs, New Jersey: Prentice Hall, Inc.

Hamalik, Oemar .(2005). Perencanaan pengajaran berdasarkan pendekatan sistem. Jakarta: PT. Bumi aksara.

Miarso, Yusuf hadi. (2004) Menyemai Benih Teknologi Pendidikan, Jakarta: Kencana Prenada Media Group.

Sardini. (2013). Pengaruh minat belajar terhadap hasil belajar.(Skripsi). Universitas Tanjungpura, Pontianak.

Sudjana, N, dan Rivai A. (2005). Media pengajaran. Bandung: Sinar Baru Algensindo.

Sudjana, nana . (2009). Penilaian hasil proses belajar mengajar. Bandung: Remaja Rosdakarya,

Sugiyono. (2013). Metode penelitian pendidikan. Bandung: Alfabeta.

Suprijono, Agus. (2010). Cooperative learning, teori dan aplikasi PAIKEM. Surabaya:Pusaka belajar.
Sutikno, Sobari, M. (2007). Rahasia sukses belajar dan mendidik anak. Matraman NTP Press

Syah, Muhibbin. (2003). Psikologi belajar Jakarta : PT. Raja Grafindo persada.

Usman, Moh.Uzer.(2002). Menjadi guru profesional . Bandung: PT. Remaja Rosdakarya

Undang Undang Republik Indonesia Nomor 20 Tahun 2003 Sistem Pendidikan Nasional. 2003.Lembaran Negara Repub;ik Indonesia Tahun 2003 No 4301.Jakarta.Di Akses Pada Tanggal 8 Juli 2019 